\title{
Best Practices in Historical Studies of Nursing and Health (1999-2017)
}

\author{
As boas práticas presentes em estudos históricos de enfermagem e saúde (1999-2017) \\ Las buenas prácticas presentes en estudios históricos de enfermería y salud (1999-2017)
}

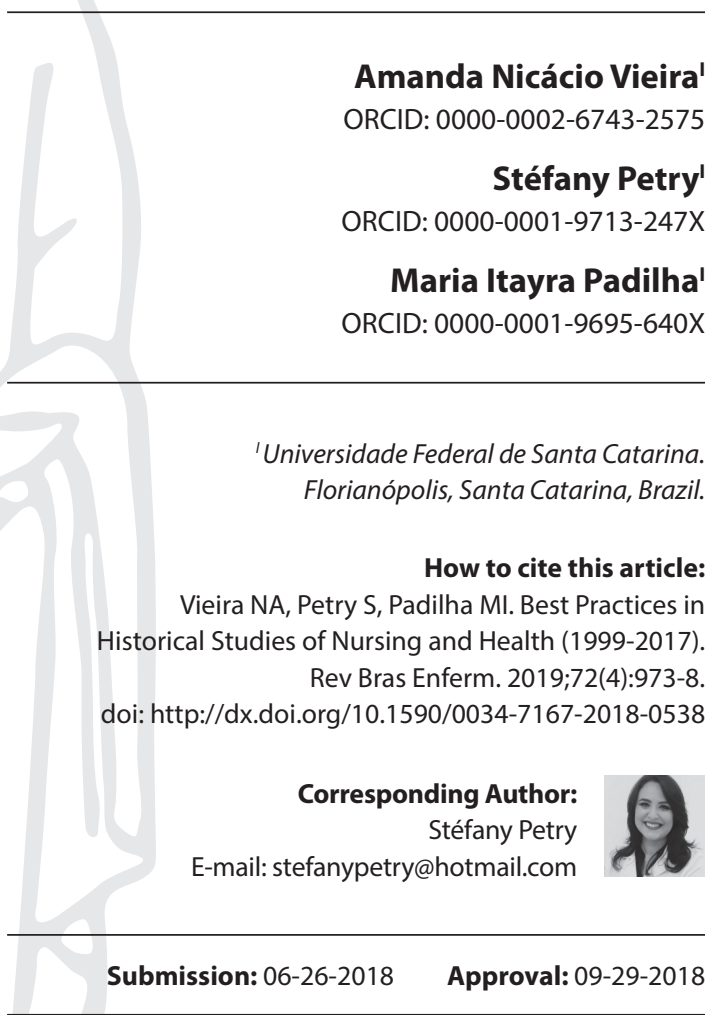

\begin{abstract}
Objective: to analyze the best practices thematic in dissertations and theses produced by a research group of history of nursing and health from 1999 to 2017. Method: a documentary socio-historical research with a qualitative approach. Documentary sources were dissertations and theses using content analysis. Results: 30 dissertations and 20 theses were found with compliance with the objective. Best practices refer to care and assistance practices, the history of institutions and organizational entities, and the implementation of nursing practices in each institution. Educational process addresses best practices in support groups, educational institutions and specialty construction. Other studies bring the milestones of the nursing profession, confrontation situations and social reflection regarding vulnerabilities. Final considerations: the studies address best practices in nursing that go through several settings in the attempt to raise problems and promote scientific research to support nursing actions in care.

Descriptors: History of Nursing; Academic Dissertations; Electronic Thesis; Nursing Education; Professional Practice.
\end{abstract}

\section{RESUMO}

Objetivo: Analisar a temática das boas práticas em dissertações e teses produzidas por um grupo de pesquisa de história de enfermagem e saúde no período de 1999 a 2017. Método: Pesquisa sócio histórica documental com abordagem qualitativa. As fontes documentais foram dissertações e teses utilizando a análise de conteúdo. Resultados: Encontradas 30 dissertações e 20 teses com aderência ao objetivo. As boas práticas abordadas referem-se a práticas do cuidado e assistência, história de instituições e entidades organizacionais e implantação das práticas de enfermagem em cada instituição. O processo educativo aborda boas práticas em grupos de apoio, instituições de ensino e construção de especialidades. Outros estudos trazem marcos da profissão de enfermagem, situações de enfrentamento e reflexão social frente às vulnerabilidades. Considerações finais: Os estudos abordam boas práticas de enfermagem que perpassam por diversos cenários na tentativa de levantar problemas e promover pesquisas cientificas para embasar ações da enfermagem na prática assistencial.

Descritores: História da Enfermagem; Dissertações Acadêmicas; Teses Eletrônicas; Educação em Enfermagem; Prática Profissional.

\section{RESUMEN}

Objetivo: analizar los temas de las buenas prácticas en disertaciones y tesis producidas por un grupo de investigación de historia de enfermería y salud en el período de 1999 hasta 2017. Método: investigación social histórica y documental con enfoque cualitativo. Las fuentes documentales fueran disertaciones y tesis utilizando el análisis del contenido. Resultados: fueran encontradas 30 disertaciones y 20 tesis con adhesión al objetivo. Las buenas prácticas abordadas se refieren a prácticas de cuidado y asistencia, historia de instituciones y entidades organizacionales y implantación de las prácticas de enfermería en cada institución. El proceso educativo trata las buenas prácticas en grupos de apoyo, instituciones de formación y construcción de especializaciones. Otros estudios traen etapas de la profesión de enfermería, situaciones de enfrentamiento y reflexión social ante las vulnerabilidades. Consideraciones finales: los estudios abordaran buenas prácticas de enfermería que cruzan diversos escenarios en el intento de levantar problemas y promover investigaciones científicas para soportar acciones de enfermería en la práctica de asistencia.

Descriptores: Historia de la Enfermería; Disertaciones Académicas; Tesis Electrónicas; Educación en Enfermería; Práctica Profesional. 


\section{INTRODUCTION}

The importance of historical research in nursing is precisely to bring situations of the past that can guide, explain or solve issues of the present by producing a critical, reflective and related reasoning to the current reality. It can be affirmed that these researches are highly influenced and inspired by the contact with the groups of researches related to the trajectory of the nursing and its historical routes $^{(1)}$. The importance of historical research in nursing is precisely to bring situations of the past that can guide, explain or solve issues of the present by producing a critical, reflective, and related reasoning to the current reality. This history permeates a field of dynamic and contradictory forces involving past, present and future ${ }^{(2)}$.

History of nursing is researched and told in different ways in various countries of the world. A study carried out in Spain states that the history of Spanish nursing is modest when compared to other AngloSaxon countries. Nonetheless, it occupies a considerable position in the availability of databases for this type of study. The study presents as a bias the non-inclusion of journals that deal exclusively with the history of nursing in some databases or databases, with only index ${ }^{(3)}$. In Brazil, a survey ${ }^{(4)}$ carried out indicates that the area of research in nursing history is still scarce, as well as the documentation centers and their precarious preservation and recognition. The importance of studies and groups of research existing in Brazil and in the world is affirmed through this, preserving the memory and historical identity.

The Laboratório de Estudos da História do Conhecimento em Enfermagem e Saúde (GEHCES - Laboratory of History of Knowledge in Nursing and Health) ${ }^{(5)}$ is one of the research groups of the Programa dePós-Graduação em Enfermagem (PPGENF-UFSC-Graduate Program in Nursing). GEHCES began its activities in 1995 after approval of research funding by the National Council for Scientific and Technological Development (CNPq - Conselho Nacional de Desenvolvimento Científico e Tecnológico). After its creation and after the $1^{\text {st }}$ prize at the $48^{\text {th }}$ Brazilian Nursing Congress with one of its works, the group began to increase the number of participants, their participation in Brazilian and international scientific events and publication of the results of their research in qualified journals ${ }^{(6)}$. After its consolidation in scientific studies in the area of history, represented especially in dissertations and theses, it was chosen to carry out this study. It was interested in pointing out, through the History of Nursing and the productions of this area, how best practices in nursing have been approached, thus highlighting the importance of historical research and its interlocution with best practices.

Why the option to search for best practices in historical studies? Socio-historical studies comprise the study of human groups in their temporal space and are concerned to discuss the varied aspects of the daily life of different classes and social groups. The contexts used for these studies may be a hospital, a school, an institution, a city and groups of individuals who were part of a particular historical moment. Developing historical research to build the nursing memory and critically analyze the history of nurses and nursing is a challenge to be faced increasingly ${ }^{(7)}$.

In this sense, its results must present sufficient support to defend best health and nursing practices. Best practices developed from studies of dissertations, theses and other means of research in nursing, have in recent times, generated new discoveries and tests that allow improving care for users, aiding in clinical management and decision-making.
Through literature searches, there was evident confusion in the concepts related to best practices in nursing and EvidenceBased Practices. In this way, it is worth clarifying both through their concepts and differentiations. Best practices in nursing are the best recommendations based on proven scientific evidence through investigations ${ }^{(8-9)}$.

The "best practice" term began to appear in the early 1990s when there was a global shift in understanding the quality of health care. This change corresponds to the emergence of scientific evidence, advances in medical and information technology, as well as growing concerns related to financing health and patient safety. This change is evidenced by the discussion height of new concepts related to the quality of nursing care evidenced through the literature, including best practices ${ }^{(10)}$.

Best practices in nursing means to perform care within its certainties in order to obtain the best possible results in the practice that is performed. Its principles base the quality of care, and direct the practice of nurses by providing ethical and respectful care based on patient and family needs, clinical excellence, and best available scientific information ${ }^{(11)}$. In this way, best practices are essentially formed by a triad that encompasses the best results of scientific research, clinical expertise and the needs of each patient/individual ${ }^{(8)}$.

The importance of development and dissemination of best practices for the nursing professional is the safe guidance of best evidences for clinical management, with periodic updating $^{(8)}$. Thus, they are considered to work in specific situations and contexts, without using excessive resources to achieve the desired results. Best practices add elements that contribute to the operation and effective success of the interventions, being the research a great strength of the nursing profession, used as a tool to change practice, education, and health policies ${ }^{(12)}$.

By making a comparison between "Best Practices" and "EvidenceBased Practices" (EBP), it is clear that both are not contradictory. However, EBP has as one of its objectives to encourage the use of research results in improving health care at different levels of care, reinforcing the importance of research for clinical practice ${ }^{(13)}$. In time, both care about qualifying health work.

EBP has the capacity to qualify work in health, and presents itself as a good strategy for clinical effectiveness. It produces bases for decision making, where the professional performs care. This practice is based on the identification of a problem and on the decision-making anchored in the knowledge already produced on the subject, adding to the knowledge acquired in practice. EBP is considered to be an integration of all scientific evidence, clinical skills, and patient singularities with respect to their condition. This practice constitutes a permanent field of knowledge, which is constantly improving and constructed, to produce analyzes and greater understanding of health phenomena ${ }^{(14-16)}$.

In view of the above, the study's guiding question emerges: what are the best practices produced in the dissertations and theses of a research group on the history of nursing and health in 1999-2017?

\section{OBJECTIVE}

This study aims to analyze the best practices thematic in dissertations and theses produced by a research group of history of nursing and health in the period from 1999 to 2017. 


\section{METHOD}

\section{Ethical aspects}

The study is a documentary research that uses as collection source documents of general and public access, in the case of these theses and dissertations. Thus, it does not require submission to the Research Ethics Committee involving human beings. Resolution 510/2016 states that surveys that use publicly available information pursuant to Law 12,527/2011 will not be registered and evaluated by the CEP (Comitês de Ética em Pesquisa - Research Ethics Committee)/CONEP (Comissão Nacional deÉtica em Pesquisa - National Research Ethics Committees) system, and surveys that use public domain information.

\section{Type of study}

This is a socio-historical research of the documentary type with a qualitative approach. The use of documents promotes the reach of information through the exploration and treatment of materials. They can be found in oral and written materials, texts of diverse genres, vestiges and administrative documents, books, among other bibliographic materials. Historical research has the documentation as method and presents processes of choice, organization, analysis and synthesis. These techniques correspond to the processes of collecting, observing and processing information, making the facts in data possible to be analyzed ${ }^{(7)}$.

\section{Data source}

The documentary sources used correspond to the dissertations and theses produced in the cut from 1999 to 2017, comprising the surveys completed during the GEHCES trajectory. This cut comprises the year 1999, where the oldest study produced by the group was found in its entirety. Studies ranging from 1995, year of creation of the GEHCES, until 1999 were not obtained in full and were withdrawn from the study object. During this period, the scientific productions of the group were guided by two leading GEHCES professors: Prof. Dr. Maria Itayra Padilha and Prof. Dr. Miriam Susskind Borenstein.

The search for these sources was carried out in the online archives system of the Universidade Federal de Santa Catarina Library (UFSC) called Pergamum, as well as a Resume of the respective counselors, personal files, e-mails and the Graduate Nursing Program Office.

\section{Collection and organization of data}

The collection period comprises the months of May and June of 2018. In the initial search, 39 dissertations and 22 theses concluded were found until 2017 , on varied topics. Regarding the productions and orientations of the leading GEHCES professors, 24 dissertations and 20 theses guided by Prof. Dr. Maria Itayra and 15 dissertations and 02 theses guided by Prof. Dr. Miriam were found.

Data collection was carried out through a tool elaborated by the authors, which included in the classification stage of the studies, data such as research title, author, guideline, subject, object, possibly addressed best practices, year, type of study and line of research, with compliance with the GEHCES group. The tool seeks to make an advanced identification of the document, as well as to delimit the relevance of the same to the study. The inclusion criteria comprise completed and found research in full. On the other hand, the exclusion criteria were researches that did not have compliance with the nursing area, such as research elaborated with a focus on physiotherapy, focused on physiotherapeutic treatments and care, and on the history of physical therapy in the city of Florianópolis. After applying these criteria and the tool for each document, 30 dissertations and 20 theses were obtained as a result.

\section{Data analysis}

Data were analyzed using the Bardin content analysis technique. This technique works the speech, taking into account its meanings (the content itself) and the forms and distributions of these contents by its emitter. It tries to understand its meanings through its emitters or immersed environment. This type of analysis is composed of three stages: pre-analysis, material exploration and treatment, and interpretation of results obtained.

The steps used were pre-analysis, material exploration and treatment, and interpretation of results (inference and interpretation) ${ }^{(17)}$. In pre-analysis, all documentary sources corresponding to the historical cut of the study were collected, and after reading all abstracts, it was possible to delimit the documents according to the study objectives. In material exploration stage, the results were grouped by similarities and the categories were formulated. After grouping the results and formulating the categories, the process of interpretation was started, according to the definitions of best practices and study objectives.

\section{RESULTS}

The 50 studies were analyzed separately and later grouped by similarities, in order to show and facilitate the understanding of the data found. Each study was applied to the tool and it was not considered necessary to divide the studies according to the production, being dissertation or thesis. In this way, groupings comprise how the compilation of all the results found.

Subsequently, groupings were carried out through the themes, subjects, and study objects found in the researches, which allowed the creation of 04 categories.

Regarding category 01,"Care and Assistance", 16 (32\%) researches are attributed to approaches of best practices performed in medical and surgical clinics, intensive care units, basic health units, community, and other types of care and health care. Regarding the themes found, the studies addressed HIV, hospitalized children, midwives, newborns, humanization in mental health, psychiatric reform, organ donation, tuberculosis and nursing care and practices.

Category 02, "Institutions and Organizations", consists of 17 (34\%) researches with best practices directed at some health institutions, higher education schools and organizational entities such as Associação Brasileira de Enfermagem (ABEn - Brazilian Nursing Association) and Conselho Regional de Enfermagem (COREn - Nusing Regional Board), addressing aspects related to these realities. Studies on the implementation and organization of nursing work were also found; insertion of the nursing technical course at Instituto Federal de Santa Catarina (Federal Institute of Santa Catarina); trajectory of AIDS in Florianópolis; history 
of the school of seamen apprentices; multidisciplinary team at Centro Catarinense de Reabilitação (Rehabilitation Center from Santa Catarina); and contribution of nursing in diverse settings.

Table 1 - General profile of research produced by Laboratorio de Estudos da Historia do Conhecimento em Enfermagem e Saude (GEHCES - Laboratory of History of Knowledge in Nursing and Health), Florianópolis, Santa Catarina State, Brazil, 2018

\section{Total}

$\begin{array}{cll}\text { Type of Study } & \text { Qualitative* } & 49 \\ & \text { Quantitative } & 01 \\ \text { Method } & \text { Documental } & 06 \\ & \text { Thematic oral history } & 25 \\ & \text { Life's history } & 05 \\ & \text { Oral history + documentary } & 04 \\ & \text { Oral history + shooting } & 01 \\ \text { Theoretical } & \text { Claude Dubar } & 02 \\ \text { Framework } & \text { Paulo Freire } & 04 \\ & \text { Eliot Freidson } & 04 \\ & \text { Paterson and Zderad's Humanistic Nursing } & 04 \\ & \text { Theory } & \\ & \text { Dorothea Orem's Self-Care Deficit Theory } & 02 \\ & \text { Erving Goffman } & 01 \\ & \text { Simone de Beauvoir and Joan Scott } & 01 \\ & \text { Arthur Kleinman } & 01 \\ & \text { Michel Foucault } & 08 \\ & \text { Social Representations Theory } & 02 \\ & \text { New History } & 04 \\ & \text { Vulnerability and risk concept } & 01 \\ & \text { Clifford Geertz } & 01 \\ & \text { Nietzsche and Schopenhauer } & 01 \\ & \text { Theoretical Framework or Memory } & 03 \\ & \text { Lazarus and Folkman's Psychological Stress } & 01 \\ & \text { and Coping Theory } & \\ \text { Did not use Theoretical Framework } & 10\end{array}$

Total of studies

Note: *Regarding the qualitative studies, 08 convergent-assistance research and 01 integrative review were found.

Category 03, “Education and Research", addresses 10 (20\%) research with a focus on educational actions with patients' families, directly with patients, in support groups, research groups, health policy implementation, and teaching and nursing specialties. Some of the topics covered permeate groups of pregnant women, group directory of CNPq, educational practice of nursing in a child development center, ludoterapia in the educational process, education with families of hospitalized children, and construction of the gerontological nursing specialty.

Category 04, "Others", addresses 07 (14\%) research on best practices aimed at the professional identity of Brazilian nursing and research that addresses issues of vulnerability as a consequence of the nursing professional's exposure to some pathologies: homeless people and drug use, social representations of sex, body, gender and sexuality, social representations of adolescents about alcoholism, and people with physical disabilities.

After delimitation and separation of the studies into categories, it was still possible to demarcate them according to the research lines of the group, in order to give global visibility of what was produced, according to their aspects ${ }^{(18)}$. It can be noticed that the line of research most worked was line 02 - the history of specialties in Health and Nursing - totaling 33 (66\%) researches in this area. Another line of research with a significant number of studies was line 03 - history of teaching and nursing practices in Brazil - encompassing 14 (28\%) surveys. The line of research 04 - professional identity in health and nursing - totaled 02 (4\%) studies and line 06 - health care of physically disabled people in Santa Catarina State, reality and challenge - had 01 (2\%) study.

It was considered that in the lines of research 01 - the history of nursing in Brazil - and 05 - the history in health nursing - no study was found aimed at these subjects. However, it can be affirmed that all the researches produced by the group are historical researches and have as axis guiding these two lines.

\section{DISCUSSION}

Nursing is moving towards a technological era which demands from the nurses new attitudes, behaviors, and ways of thinking and being. It is important to know the impact of scientific research and its influences, in the sense of validating knowledge and producing evidence that subsidizes its application in care ${ }^{(19)}$. It was decided to use the term "Female Nurse Professional" in the discussion of data, because the group's productions are most often produced by female nurses.

The historical studies used as data source for this research did not focus on the use of the best nursing practices. Nonetheless, the studies were concerned and sought to highlight best practices through studies aimed at the human being within the scope of their individual, collective, and social health.

Best practices can be carried out in different environments, to take action or solve a problem. They can be validated after their application, observation or documentation, from studies, manuals or guidelines ${ }^{(20)}$. Best practice principles are based on a set of systematic measures that should generally be carried out by the entire multidisciplinary and interdisciplinary team. They must respect the diversity and inter-relationships between them, which implies the need for good communication and relationship between team members ${ }^{(21)}$.

From the GEHCES research surveys, it can be stated that care is the main and guiding focus of best practices. It is indispensable to produce studies focused on best practices in care and quality of care delivery, which should be disseminated in the areas of teaching, research and care practice. Meanwhile, the reality of assistance still has some barriers such as lack of time, high demand and new information, lack of familiarity and inadequate identification of a real research problem, making it difficult to resolve some conflict ${ }^{(22)}$. Given this, the GEHCES studies focused on care have the participation of different health professionals. It reinforces the multi-interdisciplinary importance, diversity of study sites and care practices related to regional and cultural knowledge, integrating the history of each person and their social environment.

In order to support the demand and the need for improved care and care by health professionals, government organizations and institutions should provide the necessary conditions 
to promote and support best practices. It should be encouraged active participation of professionals who carry out their activity in the context of clinical practice and integrated provision as a source for research and scientific research projects. It is fundamental to study these institutions and their way of organizing and implementing their work process, reflecting on patient care, interpersonal relationships, and ambience ${ }^{(22)}$. Moreover, the group's research portrays the institutions and their services making a joint and rescue of the implantation, creation and operation of the services, according to the objectives and historical periods of each one. It also deals with topics such as the nursing process and its adaptation processes in health institutions, as well as the implementation of the undergraduate nursing course in a technological institute.

It is expected from teaching institutions that teaching-learning will be based on the best scientific evidence, so that future professionals can have this knowledge and use them when they act in the practice of care. These professionals feel safer to learn the content in an updated way and with levels of evidence reflecting on their performance, community, and social environment ${ }^{(22-23)}$. Best practices, in terms of health organizations, are the ones that through the application of techniques or methodological procedures, have proven reliability to generate a certain positive result ${ }^{(8)}$.

Several researches were found that had as main objective the setting of the Primary Health Care, approaching practices directed to health professionals and their conduits at work in care provision. Best practices in nursing, in any field of action, must contain some assumptions and principles. They are part of a set of health devices that are arranged, in an articulated way, to supply the monitoring, intervention, evaluation of intervention in health and disease processes of social groups throughout the territory ${ }^{(24)}$.

Health education implicit in nursing work can use educational technologies that serve as mediating devices and facilitators of the dissemination of knowledge and information. Its use and application needs attitudes that make it possible to respond to the audience for which it is intended ${ }^{(25)}$. Faced with this, GEHCES productions have as objectives to portray several realities and processes of teaching, creation and formulation of some specialties, teaching-learning processes in a collective way, involving community, research and care of themselves.

Another relevant point in the study of best practices is the personal dimension. Nurses should clearly understand their importance to professional practice and its benefits/mishaps for the future of the profession ${ }^{(23)}$. Along with this, GEHCES is concerned with the nursing professional's identity and seeks to show in its studies its history, legislation, events that are significant for the profession and its development in Brazil(6). Besides professional identity, professional's identity is also portrayed according to the health or teaching institution, pointing out their influences, knowledge, and ways of organizing care.

Best practices related to situations of vulnerability advise the researcher so that the subject studied expresses their feelings and fears, causing them to reflect on their situation, and has encouragement to deal with each situation. This type of study facilitates the understanding of these groups of people and serves as the north for the implantation of social care and reflection plans ${ }^{(26)}$.
Sharing information in a documented and well-founded manner makes it possible to avoid errors that may be repetitive. Sharing best practice is to enable health professionals and organizations to have a better opportunity to gain knowledge and improve performance. Best practices allow the creation and adaptation of strategies and activities through feedback, reflection, and analysis of how to implement broad, sustainable and effective interventions ${ }^{(12)}$.

The importance of addressing best practices in scientific research permeates social, professional, scientific and organizational issues, each having a fundamental point for exploration and application in clinical practice.

\section{Study limitations}

Regarding the study limitations, it is possible to mention the significant number of studies that contemplated this research, and it is not possible to expose in a more detailed way the best practices specifically addressed in each of the theses and dissertations produced by the research group.

\section{Contributions to the Nursing field}

The study developed has relevance not only in the scientific construction, but also presents the importance of studies in the historical area that allows pointing the past and the present, in order to expose possible changes in the future. It makes possible to understand that best practices in nursing have social importance in the academic and practice setting, being a field that needs to be explored and studied in order to promote nursing actions.

\section{FINAL CONSIDERATIONS}

Best practices in nursing permeate several practice and teaching settings in order to implement improvements through the evidences found. Thus, it can be observed that studies from a historical perspective also go beyond and integrate the different settings of nursing practice in an attempt to identify a problem that can be explored and analyzed.

It is understood that nursing has as a work tool the care, and what subject is the object of nursing work. In this way, combination of these means allows for numerous possibilities of studies and interventions in order to provide improvements in the quality of care provided, in interpersonal relationships at work and in the way of work and organization of institutions. In the studies found, they were verified in two different areas of performance and research, that best practices are a topic that needs to be approached more frequently. It promotes advances in terms of operationalization of the results of the scientific researches that occur due to mishaps faced in the daily routine of the nurse.

It is remarkable the importance of historical research for the development of best practices aimed at different nursing areas and its evolution over the years. From this study, it is recommended that the research groups in each domain area continue to question and investigate what is not yet enlightening and safe in clinical practice in nursing, and advancing according to the demand and global social requirements. 


\section{REFERENCES}

1. Padilha MI, Ferreira AC, Maliska ICA, Villarinho MV, Zykuewisz GV, Sell C. Recent trends in scholarship on the history of nursing in Brazil. Hist Cienc Saude-Manguinhos. 2013;20(2):695-707. doi: 10.1590/S0104-59702013000200019.

2. Teixeira VMN, Cunha YMM. Nursing history research: review of publications 2000-2008. Rev Min Enferm. 2011;15(3):435-42. doi: S1415-27622011000300018

3. Mínguez MI, Siles GJ. Evolution of scientific history production in Spanish nursing 1966-2013. Enferm Glob. 2015;14(39):273-90. doi: 10.6018/eglobal.14.3.204661

4. Padilha MI, Borenstein MS, Carvalho MAL, Ferreira AC. Nursing history research groups: a Brazilian reality. Rev Esc Enferm USP. 2012; 46(1):192-99. doi: 10.1590/S0080-62342012000100026

5. Universidade Federal de Santa Catarina. Laboratório de Estudos de História do Conhecimento da Enfermagem e Saúde: Sobre o Grupo [Internet]. Sobre o Grupo. 2017[cited 2018 Jun 20]. Available from: http://gehces.paginas.ufsc.br/

6. Padilha MI, Borenstein MS. Enfermagem em Santa Catarina: recortes de uma História (1900-2011). Florianópolis: Editora Secco; 2011.272 p.

7. Padilha MI, Bellaguarda MLR, Nelson S, Maia ARC, Costa R. The use of sources in historical research. Texto Contexto Enferm. 2017;26(4):e2760017. doi: 10.1590/0104-07072017002760017

8. Silva GA. Implementation of clinical best practice Guidelines Done by the Registered Nurses's Association of Ontario (RNAO) in the nursing curriculum at Universidad de Chile. Medunab [Internet]. 2015 [cited 2018 Jun 20];17(03):182-89. Available from: https://revistas.unab.edu. co/index.php/medunab/article/view/2383/2043

9. Luís SPD, Costa MGFA, Casteleiro CSC. Good practices in the stump cord care: a study review. Millenium: J Educ Technol Health [Internet]. 2014 [cited 2018 Jun 20];33-46. Available from: http://revistas.rcaap.pt/millenium/article/view/8107/5706

10. Nelson AM. Best practice in nursing: a concept analysis. Int J Nurs Stud. 2014;51. doi: https://doi.org/10.1016/j.jinurstu.2014.05.003

11. Pedreira MLG. Práticas de enfermagem baseadas em evidências para promover a segurança do paciente. Acta Paul Enferm. 2009;22(spe):880-1. doi: 10.1590/S0103-21002009000700007

12. Organização Mundial da Saúde-OMS. Guia para a Documentação e Partilha das "Melhores Práticas" em Programas de Saúde [Internet]. Escritório Regional Africano Brazzaville: OMS; 2008[cited 2018 Jun 20]. Available from: http://afrolib.afro.who.int/documents/2009/pt/GuiaMelhoresPratica.pdf

13. Mendes KDS, Silveira RCCP, Galvão CM. Integrative literature review: a research method to incorporate evidence in health care and nursing. Texto Contexto Enferm. 2008;17(4):758-64. doi: 10.1590/S0104-07072008000400018

14. Majid S. Adopting evidence-based practice in clinical decision making: nurse's perceptions, knowledge, and barriers. J Med Libr Assoc. 2011;99(3). doi: 10.3163/1536-5050.99.3.010

15. Lacerda RA, Nunes BK, Batista AO, Egry EY, Graziano KU, Angelo M, et al. Evidence-based practices published in brazil: identification and analysis studies about human health prevention. Rev Esc Enferm USP. 2012;46(5):773-82. doi: 10.1590/S0080-62342011000300033

16. Barría-Pailaquien RM. Practice Based on Evidence: An opportunity for quality care. Inv Educ Enferm. [Internet] 2013 [cited 2018 Jun 20];31(2). Available from: https://aprendeenlinea.udea.edu.co/revistas/index.php/iee/article/view/16009/14006

17. Bardin L. Análise de conteúdo. São Paulo: Edições 70; 2016.

18. CNPq. Diretório de Grupos de Pesquisa. Laboratório de Pesquisas em História do Conhecimento da Enfermagem e Saúde (GEHCES). Available from: http://dgp.cnpq.br/dgp/espelhogrupo/4293723680847197.

19. Pedrolo E, Danski MTR, Mingorance P, Lazzari LSM, Méier MJ, Crozeta K. A prática baseada em evidências como ferramenta para prática profissional do enfermeiro. Cogitare Enferm. 2009;14(4). doi: 10.5380/ce.v14i4.16396

20. Souza GF, Nascimento ERP, Lazzari DD, Boes AA, lung W, Bertoncello KC. Good nursing practices in the intensive care unit: care practices during and after blood transfusion. Rev Min Enferm. 2014;18(4):947-54. doi: 10.5935/1415-2762.20140069

21. Orue IT, Benavides BC, Alonso BR, Hernandez AIJ, Zabala JP. El cumplimiento de la buena práctica de enfermería en los ensayos clínicos. Invest Educn Enferm [Internet]. 2011 [cited 2018 Jun 20];29(1):118-25. Available from: https://dialnet.unirioja.es/servlet/ articulo?codigo $=3731991$

22. Bandeira AG, Witt RR, Lapão LV, Madruga JG. The use of a methodological framework in the implementation of evidence as part of nursing research. Texto Contexto Enferm. 2017;26(4):01-07. doi: 10.1590/0104-07072017002550017

23. Pereira RPG, Cardoso MJSPO, Martins MACSC. Atitudes e barreiras à prática de enfermagem baseada na evidência em contexto comunitário. Rev Enf Ref 2012;3(7):55-62. doi: 10.12707/RIII11146

24. Egry EY. A glance at the good practices of nursing in primary care. Rev Bras Enferm. 2018;71(3):930-1. doi: 10.1590/0034-7167.2018710301

25. Teixeira E, Medeiros HP, Nascimento MHM. Referenciais metodológicos para validação de tecnologias cuidativo-educacionais. In: Nietsche EA, Teixeira E, Medeiros HP. Tecnologias cuidativo-educacionais: uma possibilidade para o empoderamentodo (a) enfermeiro(a)? Porto Alegre: Moriá; 2014. p.113-27.

26. Toledo VP, Motobu SN, Garcia APRF. Sistematização da Assistência de Enfermagem em Unidade de Internação Psiquiátrica. Rev Baiana Enferm. 2015;29(2):172-79. doi: http://dx.doi.org/10.18471/rbe.v29i2.11707 